\title{
Bariatric Surgery and Liver Function Tests in Nonalcoholic Fatty Liver Disease
}

\author{
Beuy Joob $^{1}$ - Viroj Wiwanitkit ${ }^{2}$
}

Published online: 16 January 2017

(C) Springer Science+Business Media New York 2017

Dear Editor,

\author{
Compliance with Ethical Standards
}

The recent report on "Bariatric Surgery and Liver Function Tests in Nonalcoholic Fatty Liver Disease (NAFLD) [1]" is very interesting. Ooi et al. concluded that "improvements in NAFLD occurred rapidly after bariatric surgery and were closely related to weight loss and metabolic factors [1]." We agree with this observation. However, the implication in the setting with high prevalence of viral hepatitis such as in East Asia might be limited. The report is usually lack of the data on the situation with concomitant problem of viral hepatitis [2]. As noted by Seto WK and Yuen [3], "the lower prevalence of obesity and the overwhelming problem of viral hepatitis in Asia" is the big concern and this can be the important factor affecting the usefulness of bariatric surgery in Asian situation.

Conflict of Interest The authors declare that they have no conflict of interest.

Ethical Approval This article does not contain any studies with human participants or animals performed by any of the authors.

Informed Consent Does not apply

\section{References}

1. Ooi GJ, Burton PR, Doyle L, et al. Effects of Bariatric Surgery on Liver Function Tests in Patients with Nonalcoholic Fatty Liver Disease. Obes Surg. 2016

2. Ricci G, Bersani G, Rossi A, et al. Bariatric therapy with intragastric balloon improves liver dysfunction and insulin resistance in obese patients. Obes Surg. 2008;18(11):1438-42.

3. Seto WK, Yuen MF. Nonalcoholic fatty liver disease in Asia: emerging perspectives. J Gastroenterol. 201616
Beuy Joob

beuyjoob@hotmail.com

Sanitation 1 Medical Academic Center, Bangkok, Thailand

2 Hainan Medical University, Haikou, China 